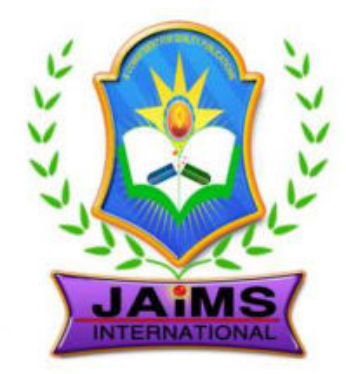

ISSN 2456-3110

Vol $4 \cdot$ Issue 6

Nov-Dec 2019

Journal of

Ayurveda and Integrated Medical Sciences

www.jaims.in

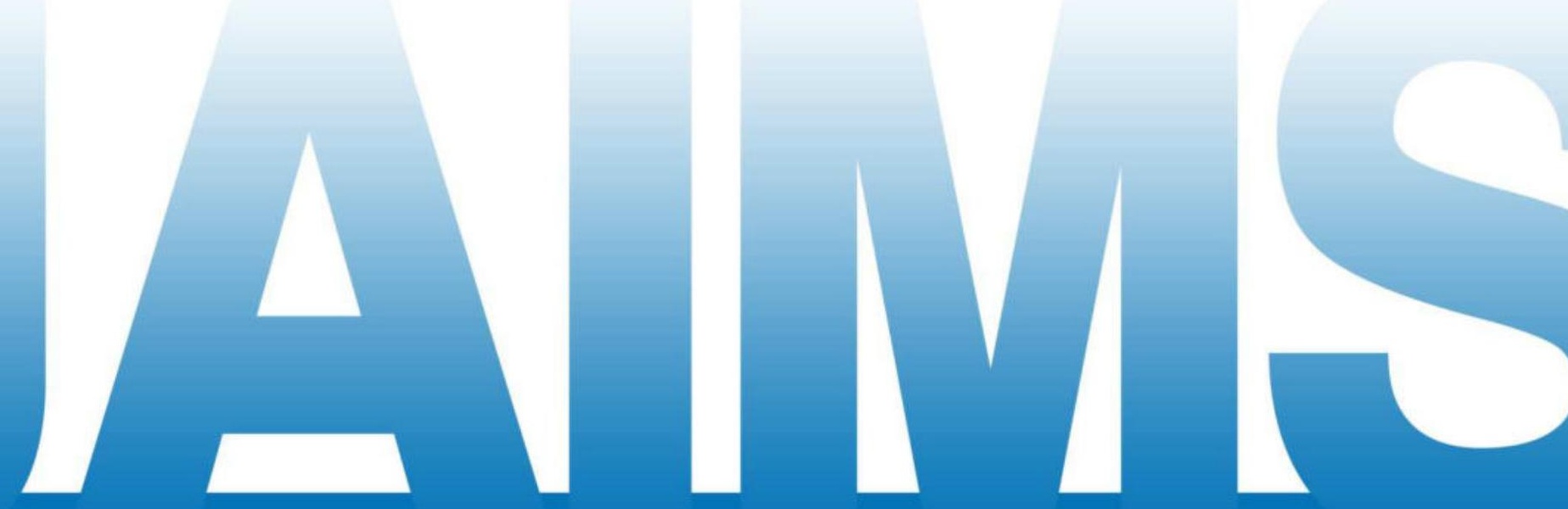

An International Journal for Researches in Ayurveda and Allied Sciences

Charaka

Publications 


\section{To evaluate the efficacy of Nasya Karma in Manyasthamba}

\author{
Dr. Jayashree P. Girisagar
}

Professor \& HOD, Dept. of Panchakarma, BVVS Ayurveda Medical College \& Hospital, Bagalkot, Karnataka, INDIA.

\section{A B S T R A C T}

\begin{abstract}
In modern era, the people adopt mechanical type of lifestyle who don't follow the proper regimen will suffer from disorders like Manyastambha. A major part of global population experiences Manyastambha atleast once in their lifetime. Manyastambha is one of the important vataja urdhvajatrugata roga the cardinal sign of Manyastambha is stiffness of neck with or without pain. Present work was undertaken to evaluate the efficacy of Nasya Karma on Manyastambha i.e. Brumhana and Shodhana therapy of mashataila is used in the Nasya Karma. In present study 30 patients are undertaken for clinical trial from Shri Mallikarjuna Swamiji Post Graduate and Research Center Bijapur. The result of Nasya Karma was having a prolonged significant results during, after and post followup of the treatment.
\end{abstract}

Key words: Nasya Karma, Masha Taila , Manyastambha, Wry Neck, Torticolis.

\section{INTRODUCTION}

Since ancient times, India is a well known world wide for its culture and its own system of medicine and that was Ayurvedic system of medicine, during this fast developing technological era the people cannot concentrate on their proper regime, facing so many disorders like Manyasthambha, but our system of medicine maintain the health with its principles. According to Charak Nasya Karma is the best Chikitsa for the Urdhwajatrugata roga (Diseases of Supraclaviculars region) in charka sidhisthana. Shirah is most important organ of the entire body. It has got most valuable place in trimarmas, head is controlling authority of the entire body because of its vital

\section{Address for correspondence:}

\section{Dr. Jayashree P. Girisagar}

Professor \& HOD, Dept. of Panchakarma, BVVS Ayurveda Medical College \& Hospital, Bagalkot, Karnataka, INDIA.

E-mail: jayashreegirisagar14@gmail.com

Submission Date: 18/11/2019

Accepted Date: 19/12/2019

\begin{tabular}{|l|l|}
\hline \multicolumn{3}{c|}{ Access this article online } \\
\hline Quick Response Code & Website: www.jaims.in \\
\hline
\end{tabular}

power. According to Acharya Charaka, "In living beings the head is the substratum of all vital and all the sense faculties". So it occupies the first place amongst the vital organs of the body. Without Nasyakarma it is not possible to eliminate the vitiated doshas and cures the diseases which are situated in the nasa, sira, manya.

Here masha taila (swalpam) for Nasya, was undertaken for the management of Manyasthambha as it does Bruhana, Lekhana, remove the Kaphavarana and mitigates vata with help of its rasa, guna, veerya, veepaka and doshagnata. Manyasthambha may be correlated to wry neck or torticolis.

Ayurvedic measures seem to be more satisfactory because, the approach is helpful to improve diseased condition, if follow the Ayurvedic principles. Then only we will be free from the disorders.

\section{OBJectives OF STUdY}

1. To evaluate the efficacy of Nasyakarma on Manyasthambha.

2. To evaluate the efficacy of Masha Taila (swalpam) Nasya on Manyasthambha. 


\section{Materials AND Methods}

\section{Materials}

Literary data: The-literary source of data for present study was obtained from classical texts of Ayurveda, modern texts and published articles in reputed journals .

Drugs:

Masha taila contains: Masha Churna, Saindhava Lavana, Tila Taila

This taila was taken for Abhyanga and Nasya

Instruments: Nasya Asana (chair cot), Dropper, Stethoscope, Goniometer, BP apparatus.

Patients: Total 30 patients diagnosed as Manyasthamba were taken for clinical study

Collection of materials

Drugs: Masha taila (swalpam)

Masha taila was purchased from B.V.V.S Bagalkot Ayurvedic College Pharmacy.

Methodology of instruments for analysis

Goniometer: Gonio means angle and meter means to measure. This consists of two arms 'one which can be fixed, while the other is freely movable mounted on a 1800 scale, which indicates the restriction of the movement, at the concerned joint when compared to normal one.

Study design: The size of sample was 30 excluding dropouts.

Nasya Vidhi: It includes Purva Karma, Pradhana Karma and Paschath Karma.

I. Purva Karma:

- Sambhara Sangraha

- Atura Pareeksha

- Atura Siddata

1. Atur pareeksha

Selection of the patient: The patients were selected according to the Inclusive and Exclusive Criteria.
Patient examined according to Dashavidha Pareeksha

2. Sambhara sangraha

Nasya asana: a) A chair for sitting

b) A cot for lying

Nasya aushadhi: Mash taila

Nasya yantra: Dropper

\section{Source of data}

Clinical data: The diagnosed patient as Manyasthamba with respect in the age group from 16 to 65 years were selected randomly from OPD and IPD and special camp conducted by Dr. BNMET'S Shri Mallikarjunas Swamiji Post Graduate and Research Centre, Bijapur. Irrespective of their sex, cast, occupation and socio economical status etc.

\section{Selection Criteria}

1. Patient diagnosed as Manyasthambha according to classical signs and symptoms

2. Patients were selected with in the age group of 16 - 65 yrs and irrespective of sex,

3. Religion occupation and social economical status.

4. Patient fulfilling the inclusive criteria

5. Patient selected were voluntarily accepted the interventions explained in details

\section{Diagnostic Criteria:}

Based on classical signs and symptoms as per the case proforma attached Annexure I.

Inclusive Criteria:

- Classically mentioned signs and symptoms of Manyasthambha.

- Patients of either sex.

- Patients in between the age group of 16 to $65 \mathrm{yrs}$.

Exlusive Criteria:

- Patients below 16 and above 65 yrs of the age.

- Pregnant women and lactating mother.

- Any other systemic disorders. 
- Any other degenerative diseases associated.

Sampling Method:

Randomly selected patients from OPD, IPD and camp conducted by Dr B.N.M E.Ts Sri Malikarjun Swamiji Post Graduate and Research center Bijapur. 30 patients were allotted in single group.

Interventions

- Study group

: 30 Patients were taken for clinical study.

- Sthanika abhynga : Masha taila (Swalpam)

- Sthanika sweda : : Tapa sweda

- Nasya Karma : Masha taila 2 drops in each nostril

- Nasya Kala

: Prataha kala at 7: 30 A.M.

- Total duration : 7 days

- Parihara Kala : : 7 days

- Follow up on $\quad: 14^{\text {th }}$ days

Subjective parameters

- Manyastambha

- Manya Shoola

Objective parameters

- Flexion

- Extension

- Left Lateral

- Right lateral

\section{RESULTS}

\begin{tabular}{|l|l|l|l|l|l|}
\hline $\begin{array}{l}\text { Manya } \\
\text { Shoola }\end{array}$ & Mean & SD & $\mathbf{t}$ & $\mathbf{p}$ & Remarks \\
\hline BT & 3.0333 & 0.6687 & 3.1063 & 0.0029 & $\mathrm{~S}$ \\
AT & 2.4000 & 0.8944 & & & \\
\hline B.T & 3.0333 & 0.6687 & 10.4689 & $\begin{array}{l}5.58820 \times 10- \\
15\end{array}$ & HS \\
PFU & 1.4333 & 0.5040 & & & \\
\hline
\end{tabular}

\begin{tabular}{|l|l|l|l|l|l|}
\hline $\begin{array}{l}\text { Manya } \\
\text { Sthambha }\end{array}$ & Mean & SD & $\mathbf{t}$ & $\mathbf{p}$ & Remarks \\
\hline BT & 2.5667 & 0.568 & 5.9210 & 0.000000 & HS \\
AT & 2.4000 & 0.894 & & 2 & \\
\hline B.T & 2.5667 & 0.568 & 12.4537 & $\begin{array}{l}4.9605 \times 1 \\
0--18\end{array}$ & HS \\
PFU & 1.1000 & 0.305 & & & \\
\hline
\end{tabular}

\begin{tabular}{|l|l|l|l|l|l|}
\hline Flexion & Mean & SD & $\mathbf{t}$ & $\mathbf{p}$ & Remarks \\
\hline BT & 2.7000 & 0.6513 & 2.9484 & 0.0046 & HS \\
AT & 2.1667 & 0.7466 & & & \\
\hline B.T & 2.7000 & 0.6513 & 3.6902 & 0.0005 & HS \\
PFU & 2.1000 & 0.6074 & & & \\
\hline
\end{tabular}

\begin{tabular}{|l|l|l|l|l|l|}
\hline Extension & Mean & S.D & $\mathbf{t}$ & $\mathbf{p}$ & Remarks \\
\hline BT & 2.5667 & $\begin{array}{l}0.6261 \\
0 T\end{array}$ & 2.5649 & 0.0129 & HS \\
\hline BT \\
PFU
\end{tabular}

\begin{tabular}{|c|c|c|c|c|c|}
\hline $\begin{array}{l}\text { Right } \\
\text { Lateral }\end{array}$ & Mean & SD & $\mathbf{t}$ & $p$ & Remarks \\
\hline $\begin{array}{l}\text { BT } \\
\text { AT }\end{array}$ & $\begin{array}{l}2.6333 \\
2.2333\end{array}$ & $\begin{array}{l}0.5561 \\
0.6261\end{array}$ & 2.6165 & 0.0113 & $\mathrm{HS}$ \\
\hline $\begin{array}{l}\text { B.T } \\
\text { PFU }\end{array}$ & $\begin{array}{l}2.6333 \\
2.1667\end{array}$ & $\begin{array}{l}0.5561 \\
0.5921\end{array}$ & 3.1468 & 0.0026 & HS \\
\hline
\end{tabular}

\begin{tabular}{|l|l|l|l|l|l|}
\hline $\begin{array}{l}\text { Left } \\
\text { Lateral }\end{array}$ & Mean & SD & $\mathbf{t}$ & $\mathbf{p}$ & Remarks \\
\hline BT & 2.5333 & 6.5713 & 3.5289 & 0.0008 & HS \\
AT & 1.9667 & 0.6687 & & & \\
\hline
\end{tabular}




\begin{tabular}{|l|l|l|l|l|l|}
\hline B.T & 2.5333 & 0.5713 & 10.3849 & $7.5156 * 10-$ & HS \\
PFU & 1.1667 & 0.3790 & & & \\
\hline
\end{tabular}

\section{DisCUSSION}

Bruhana Nasya: According to Sushruta, the benefit of using Brumhana Nasya may be perceived in variety of ways due to sapta dhatukshaya, the vitiation of vata dosha is occurred. The dhatu kshaya is controlled by using Nasya, this Nasya acts as nourishment to the dhatus present in the head and neck regions due to this Nasya vata dosha is reduced and maintained samyavastha of vata. It is especially useful in vataja shiroroga and manyasthabha.

\section{Probable mode of action of Masha taila}

"Nasa Hi Shirsao Dwaram", Acharya Sushruta has explained there is communication between the Nasal cavity and cranial cavity. The Cranial and Nasal cavity are significant cavities in the head and neck region. It is mainly based on procedure and therapeutic effect.

\section{Nasal and Cranial cavity}

The medicine will enter from the nasal cavity to the cranial cavity and reaches the centers, through the foramens in the cribriform plate. Which transmits the nerves and blood vessels, will make communication between the nasal and cranial cavity.

\section{CONCLUSION}

Manyasthambha is Vatavyadhi, specific Nidanas has been not mentioned, common nidanas for vata vyadhi can be taken. Occupational, postural hazards and those who are using hard pillow are prone to manyasthambha. The symptomatology of Manyasthambha and the wry neck are strikingly similar. Due to nidana sevana, vata and kapha dosha vitiates, involving rasa, mamsa and vatavaha srotas resulting in sanga and manifest manyasthambha. The study shows that sthambha is pratyatma lakshana with shoola or without shoola. Mashya Taila Nasya Karma is having a prolonged action as it is having highly significant during, after and post follow up of treatment.

\section{REFERENCES}

1. Gupta K. A. Vaghbhatas astanga sangraha with hindi commentary printed Varanasi, Krishnadasa academy 1993:808

2. Shastri S. N., charaka samhita $22^{\text {nd }}$ edition, Varanasi chaukhambha bharati academy 1996:1070

3. Shastri R. G. Vedome Ayurveda $1^{\text {st }}$ ed, Delhi Madan Mohanlal Ayurvedic Anusandhana Trust 1956:58

4. Shastri S. N., charaka samhita $22^{\text {nd }}$ edition, Varanasi chaukhambha bharati academy 1996:195

5. Shastri K. A. Sushruta samhita $11^{\text {th }}$ edition,Varanasi chaukhambha Sanskrit sansthan 1997:182

6. Shailaja Srivastava sharangadhara samhita $2^{\text {nd }}$ edition, Varanasi chaukhambha orentalia 1998:47

7. Shastri K. A. Sushruta samhita $11^{\text {th }}$ edition, Varanasi chaukhambha Sanskrit sansthan, 1997:182

8. Vaidya P. T. Kashyapa samhita $7^{\text {th }}$ edition, Vrdhagivakiyantra chaukhambha vishwabharati 2002:269

9. Shailaja Srivastava sharangadhara samhita $2^{\text {nd }}$ edition, Varanasi chaukhambha orentalia 1998:47

10. Vaidya Haridas Shridhar Kasturi, $5^{\text {th }}$ edition Shri Bhaidhanatha Ayurveda Bhavan Academy 1996:1071

How to cite this article: Dr. Jayashree P. Girisagar. To evaluate the efficacy of Nasya Karma in Manyasthamba. J Ayurveda Integr Med Sci 2019;6:2629.

http://dx.doi.org/10.21760/jaims.4.6.5

Source of Support: Nil, Conflict of Interest: None declared. 